\title{
Growth Evaluation of Oreochromis niloticus (Cichlidae, Neopterygii) Exposed to Trichlorfon
}

\author{
Ana Tereza Bittencourt Guimarães ${ }^{1 *}$ and Patrícia Calil ${ }^{2}$ \\ ${ }^{1}$ Universidade Positivo; Rua Pedro Viriato Parigot de Souza, 5300; 81280-330; anat@brturbo.com.br; Curitiba - \\ PR - Brasil. ${ }^{2}$ Setor de Ciências Biológicas; UFPR; Centro Politécnico; C.P.: 19020; 81531-980; Curitiba - PR - \\ Brasil
}

\begin{abstract}
The aim of this work was to evaluate the influence of Trichlorfon on the growth of cultured fishes. Using Oreochromis niloticus as fish model, bioassays were performed in the laboratory and field. Biometry was performed for 16 weeks. The treatment started after the sixth week of biometry, with the application of five weekly doses of 0.25 ppm of Trichlorfon. Growth data were compared by longitudinal analyses. In the laboratory, the treated fishes showed a reduction of growth; however, the statistical significance was only seen in the variable weight. In the field, the growth of treated fish was higher than that of the controls. This suggested that the treatment should be done in tanks with lower relative biomass to maintain the good zootechnic characteristics of fishes.
\end{abstract}

Key words: Organophosphate, Tilapia, and aquaculture

\section{INTRODUCTION}

Brazilian fishery production is strongly based on the culture of exotic species, especially Tilapia (Oreochromis niloticus Linnaeus, 1758). Between 1990 and 1998, there was a considerable increase in its culture, equivalent to an increase of $30.35 \%$ (FAOSTAT, 2004). With the growing import of this species, an introduction of parasites has concomitantly occurred, causing diseases that so far were not well known in Brazilian territory. With the parasites infestation in the juvenile, a decrease in growth, weight and length rates in fish was observed (Ostrensky and Boeger, 1998), affecting directly the commercial activity of the culture. Gesamp (1997) and Mackinnon (1997) recommended combat against parasite infestations, especially based on the organophosphates in order to control the sickness and reduce the culture losses. Most of the organophosphates used against fishes ectoparasitosis contain Trichlorfon as the active commencement (2, 2, 2 trichloride - 1 hydroxietilphosphate) (Roth et al., 1993; Howe et al., 1994; Sievers et al., 1995; Tojo and Santamarina, 1998; Chandrasekara and Pathiratne, 2005). Its action depends on $\mathrm{pH}$ and temperature, being more active in temperatures above $16^{\circ} \mathrm{C}$ (Messenger and Esnault, 1992; Howe et al., 1994). When $\mathrm{pH}$ is above 8.0, its hydrolysis is extremely fast, increasing then its toxicity, and requiring, therefore, lower concentrations for the treatments (Messenger and Esnault, 1992). In aqueous solution, Trichlorfon is transformed in Dichlorvos, which is a powerful cholinesterase inhibitor (Eto, 1974; Hofer, 1981). Dichlorvos blocks central ganglion cholinergic activity in invertebrates, which usually cause sicknesses in fishery and other forms of culture (Mackinnon, 1997).

\footnotetext{
${ }^{*}$ Author for correspondence
} 
The doses utilized in fish farming are extremely low, being more toxic to parasites than to fish and man (Brandal and Egidius, 1979; Mackinnon, 1997). The $\mathrm{LC} 50_{(96 \mathrm{hs})}$ of Trichlorfon to rainbow trout is $1.4 \mathrm{mg} / \mathrm{L}$ (Hill and Camardese, 1986) and the $\mathrm{LC} 0_{(96}$ hs) of Diazinon to Oreochromis niloticus is $3.85 \mathrm{mg} / \mathrm{L}$, and steady-state accumulation, at a concentration of $28.45 \mathrm{mg} / \mathrm{kg}$, was reached at 7.72 days (Palacio et al., 2002). These doses were higher than the dose utilized in treatments against ectoparasitosis $(0.25 \mathrm{mg} / \mathrm{L})$ (Gesamp, 1997; Mackinnon, 1997, Sievers et al., 1995).

However, even in extremely low doses, these products may cause a decrease in the fish growth rates, mainly due to its primary effects in cholinesterase inhibition (Sturm et al., 1999) and consequently appetite loss and mobility decrease (Silva de Assis et al., 1993). These toxic effects in biochemical and physiological systems in an organism are also evaluated by a study in morphological cellular alterations (Hinton and Lauren, 1990; Fulton and Key, 2001; Veiga et al., 2002). In cases of contamination, fish gills and liver are the organs that mostly suffer precociously the pollutants effects, including organophosphates (Murty, 1986; Richmonds and Dutta, 1989; Machado and Fanta, 2003).

Products that have the Trichlorfon as active commencement are used in Brazilian fish cultures indiscriminately, repeatedly, in high concentrations, and without specialized technical orientation. The lack of adequate technical orientation may result in a series of serious problems related to production costs. Most known studies are about the effect of organophosphate over cholinesterase enzyme activities. However, they do not focus the consequences of the treatments in the size and the fish health, which may result in economic losses to the producer. Therefore, this study aimed to evaluate whether the treatment with Trichlorfon, in order to combat fish ectoparasites, decreased growth rates in Oreochromis niloticus.

\section{MATERIALS AND METHODS}

\section{Laboratory Growth Rate Index}

Bioassays were done in eight $40 \mathrm{~L}$ aquaria. Four of them were considered as controls and four exposed to the treatment with Masoten ${ }^{\circledR}$-Bayer, S.A (active commencement Trichlorfon). In each aquarium, 10 fishes were kept, obtained from the fish farm "Experimental Fish Farm of Canguiri, in the Federal University of Paraná), in Piraquara PR". All fishes (control and treated) had gill arches with monogenoid parasites. Abiotic factors as biological filtering $(180 \mathrm{~L} / \mathrm{h})$, temperature $(24 \pm$ $\left.1^{\circ} \mathrm{C}\right), \mathrm{pH}(7.2 \pm 0.5)$, and aeration were kept constant during the experimental period. Fishes were fed two times a day with extruded fish food (38\% protein), in a portion of $5 \%$ from the total biomass (in $\mathrm{g}$ ) of the aquarium. Aquarium maintenance was done weekly, and the food remaining in the bottom was siphonated, having $20 \%$ of the total water replaced by the clean water. After a seven-day period of acclimation, biometry process was initiated, being done biweekly during 16 weeks. Mean and standard deviation of fish weight from control and treated groups in initial time $\left(\mathrm{T}_{0}\right)$ were $2.30 \pm 0.18 \mathrm{~g}$ and $2.32 \pm 0.11 \mathrm{~g}$, respectively. Average and standard deviation for total length were $50.34+0.96 \mathrm{~g}$ and $50.74+0.74$, respectively. Relative biomass average of fish in the aquarium was $0.58 \mathrm{~g}$ of fish/L of water.

After a third biometry proceeded on the sixth week of experiment, four aquaria were submitted to weekly treatment of $0.25 \mathrm{mg} / \mathrm{L}$ of Masoten ${ }^{\circledR}$ Bayer, S.A. (active commencement Trichlorfon), for five weeks (Gesamp, 1997; Mackinnon, 1997, Sievers et al., 1995). After the end of the treatment, the control and the treatment aquaria were washed, with both groups submitted to the same level of stress. Fishes from such groups were then measured for five more weeks to evaluate the effect of the product over growth rates. At the end of the experimental period the animals were sacrified, and the presence or the absence of parasites in the gills was observed.

\section{Culture Environment Growth Rate Index}

About 12 tanks of $12 \mathrm{~m}^{3}(3 \times 4 \times 1 \mathrm{~m})$ located at the Experimental Fish Farm of Canguiri, in the Federal University of Paraná, stocked 30 individuals each. Six tanks were considered as control and the others were submitted to the treatment with organophosphate. All the fishes (control and treated) had gill arches with monogenoid parasites. Mean and standard deviations for weight and total length of control and treated fish, at the beginning of the experiment $\left(\mathrm{T}_{0}\right)$, were $5.14+0.19 \mathrm{~g}$ and $69.17+0.90$, and $5.08 \pm 0.20 \mathrm{~g}$ and $68.7 \pm 1.04 \mathrm{~g}$, respectively. Relative biomass average was $0.02 \mathrm{~g}$ of fish/L of 
water. Fishes were fed with extruded food (38\% protein) in an initial proportion of $5 \%$ of total biomass of the tank, two times a day. Biometry was started after the acclimation period, every two weeks for 16 weeks. After the sixth week of biometry, the treatment with Masoten ${ }^{\circledR}$-Bayer, S.A. was started, as previously described.

By the end of the five-week-treatment, the water was renewed, eliminating thus the remaining product. Fishes were measured during another five weeks to evaluate the product effects for a medium period over growth. Abiotic factors such as temperature, $\mathrm{pH}$, and dissolved oxygen were followed daily during the whole experiment. Average and standard deviations of such factors were gotten during mornings and afternoons: temperatures of $23.2 \pm 0.39^{\circ} \mathrm{C}$ and $25.5 \pm 0.41^{\circ} \mathrm{C}$; $\mathrm{pH}$ of $5.9+0.04$ and of $6.2+0.16$; and dissolved oxygen of $4.4+0.51$ and of $8.5+0.52$. At the end of the experimental period the animals were sacrified, and the presence or absence of parasites in the gills was observed.

\section{Data analysis}

The weight and length of all the groups were analyzed in a normal distribution (Shapiro-Wilk, $p$ $>0.05$ ) before the start of the experiment and were compared with the tretments by using t-Test for independent samples $(\propto=0.05)$, in order to verify if the pre-experimental situation was the same among the groups. No significant difference was observed between the total length of the control fishes and the treated ones $(\mathrm{t}=0.07 ; \mathrm{DF}=78 ; \mathrm{p}=$ $0.94)$, neither between the weights of such groups $(\mathrm{t}=0.05 ; \mathrm{DF}=78 ; \mathrm{p}=0.96)$. Same situation was observed in the experiment done in field (length: $t$ $=1.03 ; \mathrm{DF}=358 ; \mathrm{p}=0.30$ and weights: $\mathrm{t}=056$; $\mathrm{DF}=358 ; \mathrm{p}=0.57$ ). Then the null hypothesis was tested that increase in weight and length of fishes submitted to treatment were equal to the control ones, and this hypothesis was tested by the t-Test for the independent samples $(\propto=0.05)$. Total growth rates in weight and total length were established from the following calculations:

$$
\frac{\text { WeightT16-WeightT0 }}{\text { WeightT0 }} * 100
$$

$$
\frac{\text { TotalLenghtT16-TotalLenghtT0 }}{\text { TotalLenghtT } 0} * 100
$$

Variations in the weight and the total length were evaluated by the longitudinal analyses, which evaluated the alteration of the variables along time (Jones, 1993). Such measurements were observed seasonally, creating several "short temporal series", which gave the standard behavior of the studied phenomenon. Hence, a curve was defined that represented the model, allowing it to make previsions of the population in a certain moment and to verify the existence of differences between the models in many subpopulations (controls and treatment).

Present data were analyzed by the Laird-Ware General Linear Mixed Model (Jones, 1993). In this model, each unit presents its own model, allowing different units to have different numbers and observation times. Model parameters were estimated by the program CAR1 (Fortran), using Kalman Filter process to estimate maximum similarity. Gradually the non-significant parameters were eliminated until a better model was found established by the criteria of Akaike information (AIC) (Jones, 1993). In the laboratory experiments each fish was considered a sampling unit, and in the field experiment each tank was considered a sampling unit because it was impossible to differ each individual. Weight and total length averages of the fishes of each tank were considered correspondent to the individual measurements (fish) assessed in the laboratory.

\section{RESULTS}

\section{Laboratory Growth Rate Analysis}

Results obtained in the laboratory experiment showed into a small difference in the rates of total length growth between the averages and standard deviations of the fishes from the control $(53.6 \pm$ $6.3 \%)$ and treatment aquaria $(49.4+1.9 \%)$, being not statistically significant $(\mathrm{t}=1.64 ; \mathrm{DF}=604 ; \mathrm{p}=$ 0.10) (Fig. 1). However, by comparing the weight growth rates, it was observed that the control animals grew $294.8+50.3 \%$ in average, while the treated ones $240.1 \pm 44.9 \%$, and this difference was statistically significant $(\mathrm{t}=2.18 ; \mathrm{DF}=564 ; \mathrm{p}$ $=0.03$ ) (Fig. 2). Longitudinal analyses did not support the hypothesis that the growth of $O$. niloticus in weight and total length were negatively influenced by the use of Trichlorfon in this experiment. In the chosen models, " $\mathrm{t}$ " represent the time in weeks, the first numerically 
initial parameter meant weight (in grams), and the others were random parameters that influence in the development of this temporal series, for example, $\mathrm{pH}$, dissolved oxygen and temperature (Figs. 3A and B). At the end of the experiment, all the fishes treated with OP were parasite free.

\section{Culture Environment Growth Rate Analysis}

In culture (field) situation, the fishes from the control tanks presented an average percentile $( \pm$ DP) of total length growth of $149.35+6.32 \%$, and of $154.11+6.71 \%$ in treated ones (Fig. 4), without any significant difference between the averages $(\mathrm{t}=0.14 ; \mathrm{DF}=2775 ; \mathrm{p}=0.89)$.
Therefore, the mean growth in weight of the control animals was of $1830.53+143.52 \%$, and the treated ones a percentile equivalent to $1962.40 \%+138.14$ (Fig. 5), also being considered as statistically equal $(\mathrm{t}=0.46 ; \mathrm{DF}=2768 ; \mathrm{p}=$ $0.65)$. Longitudinal analyses did not support the hypothesis either that the growth of $O$. niloticus in weight and total length were negatively influenced by Trichlorfon. The defined models followed the same pattern determined to the equations elaborated for the laboratory experiments (Figs. $6 \mathrm{~A}$ and $\mathrm{B})$. At the end of the experiment, all the fishes treated wuith OP were parasite free.

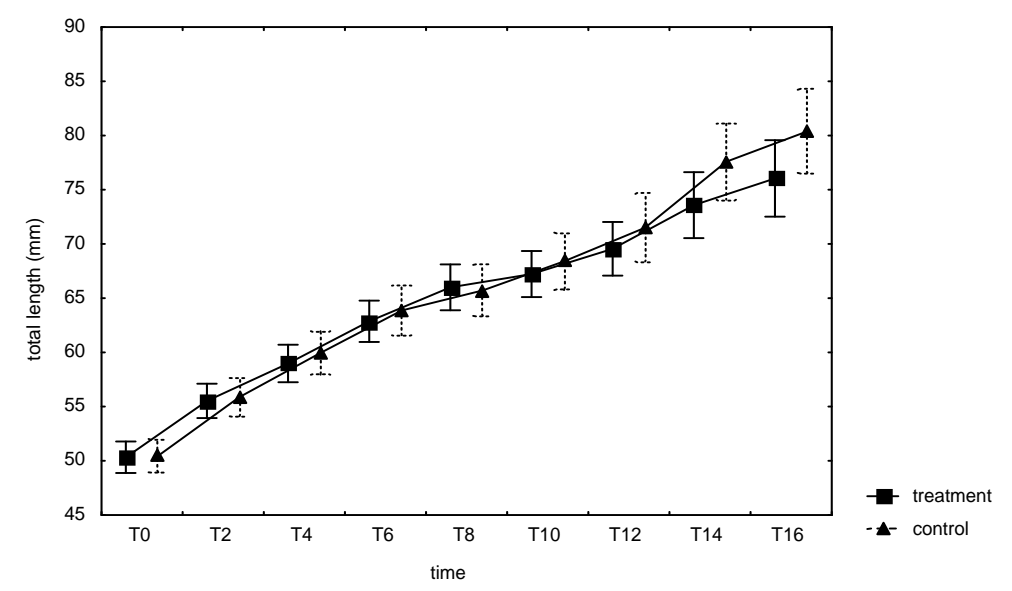

Figure 1 - Mean and standard deviations of growth in total length of control animals and the ones submitted to the treatment with Trichlorfon, in laboratory

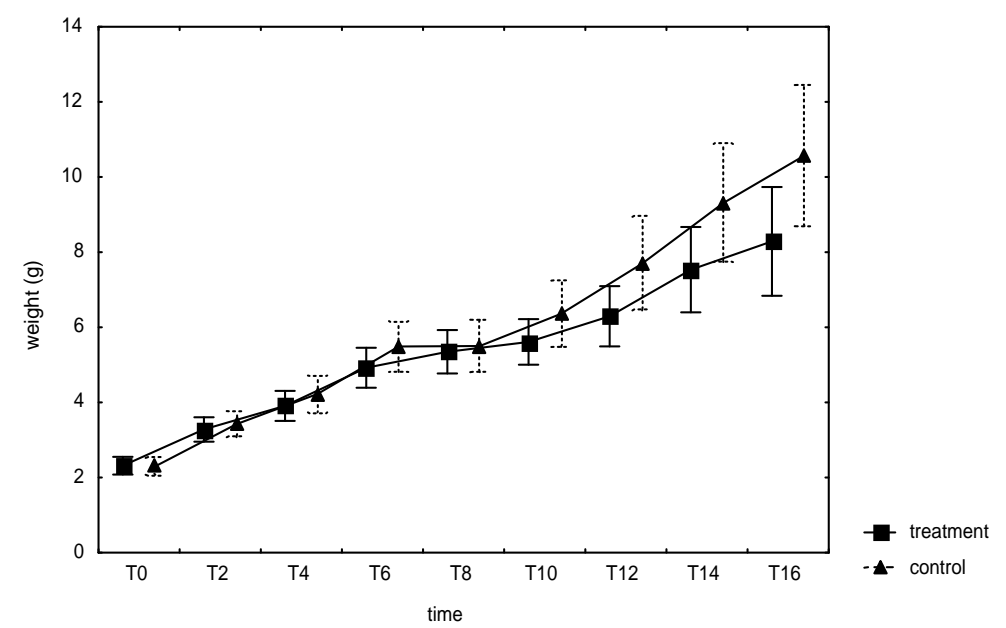

Figure 2 - Means and standard deviations of growth in weight of control animals and of the ones submitted to the treatment with Trichlorfon, in laboratory 

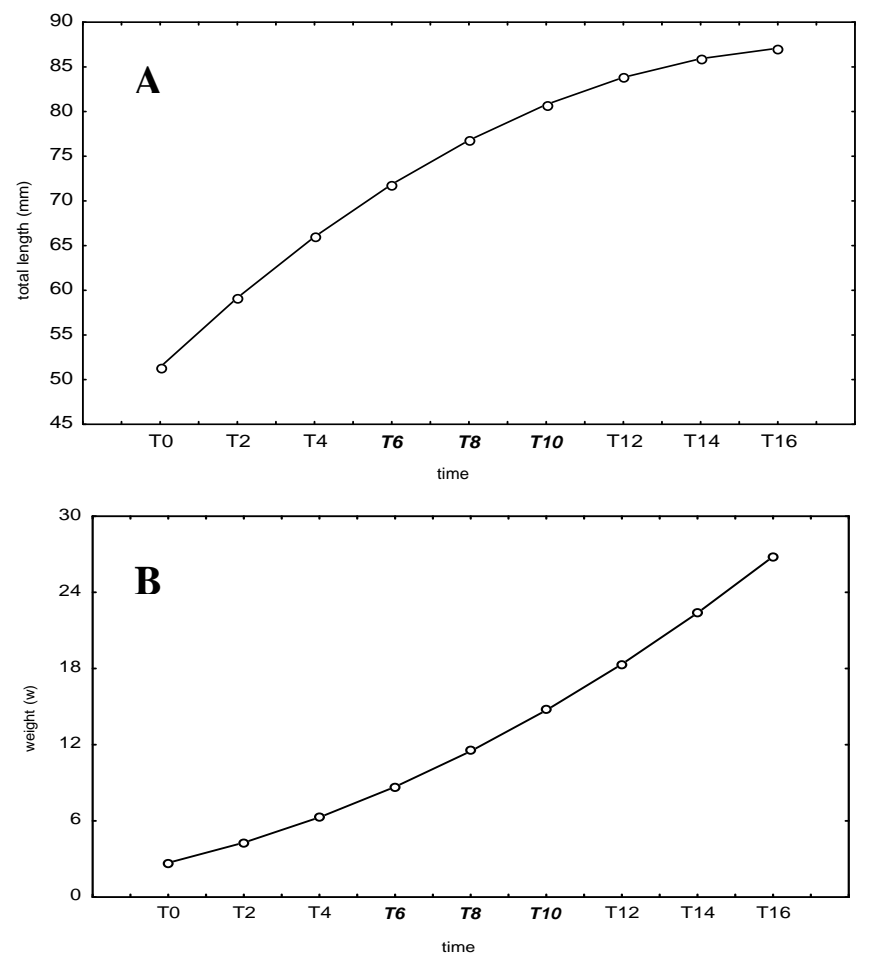

Figure 3A and B - Model adjusted through longitudinal data analysis (Controls and Treatments). A - Total length $(\mathrm{tl})=41.40+4.118 * \mathrm{t}-0.118 *(\mathrm{t})^{2} ; \mathrm{t}=$ time (biweekly). B Weight $(\mathrm{w})=2.695+0.6919 * \mathrm{t}+0.0510 *(\mathrm{t})^{2} ; \mathrm{t}=$ time (biweekly)

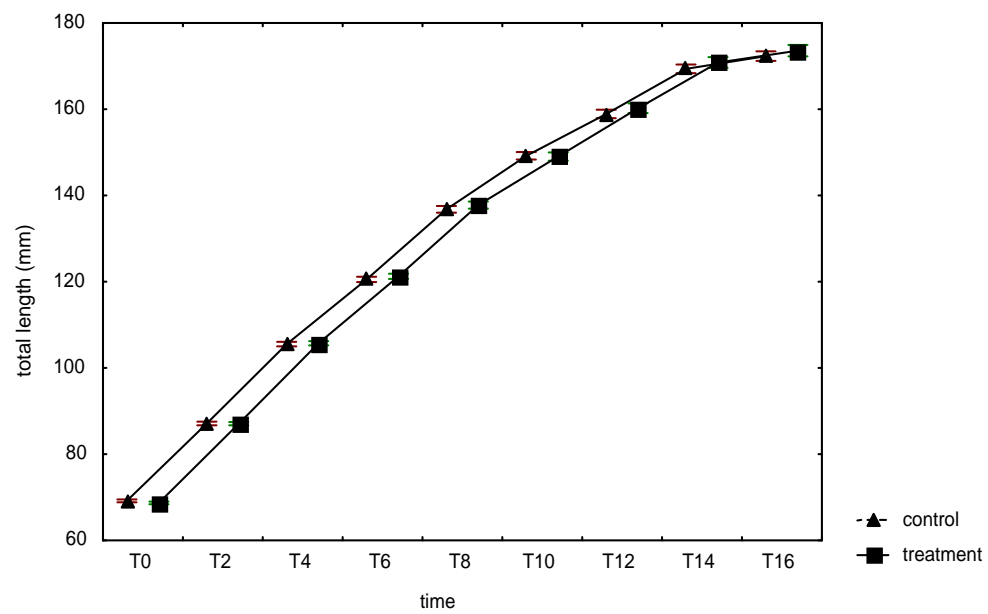

Figure 4 - Means and standard deviations of growth in total length in control animals and the ones submitted to the treatment with Trichlorfon, in culture/field environment 


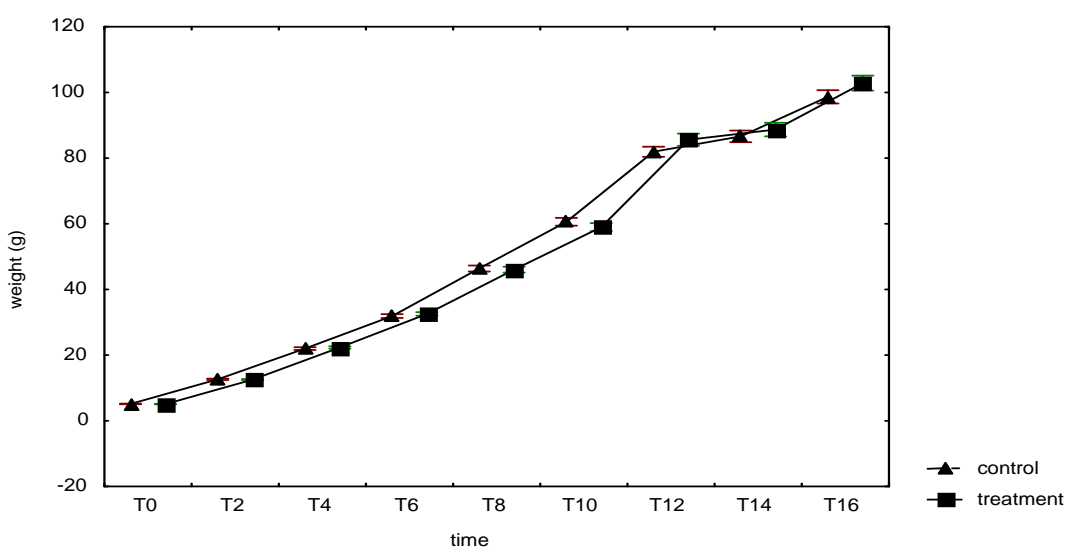

Figure 5 - Mean and standard deviations of growth in weight of control animals and the ones submitted to the treatment with Trichlorfon, in culture/field environment.
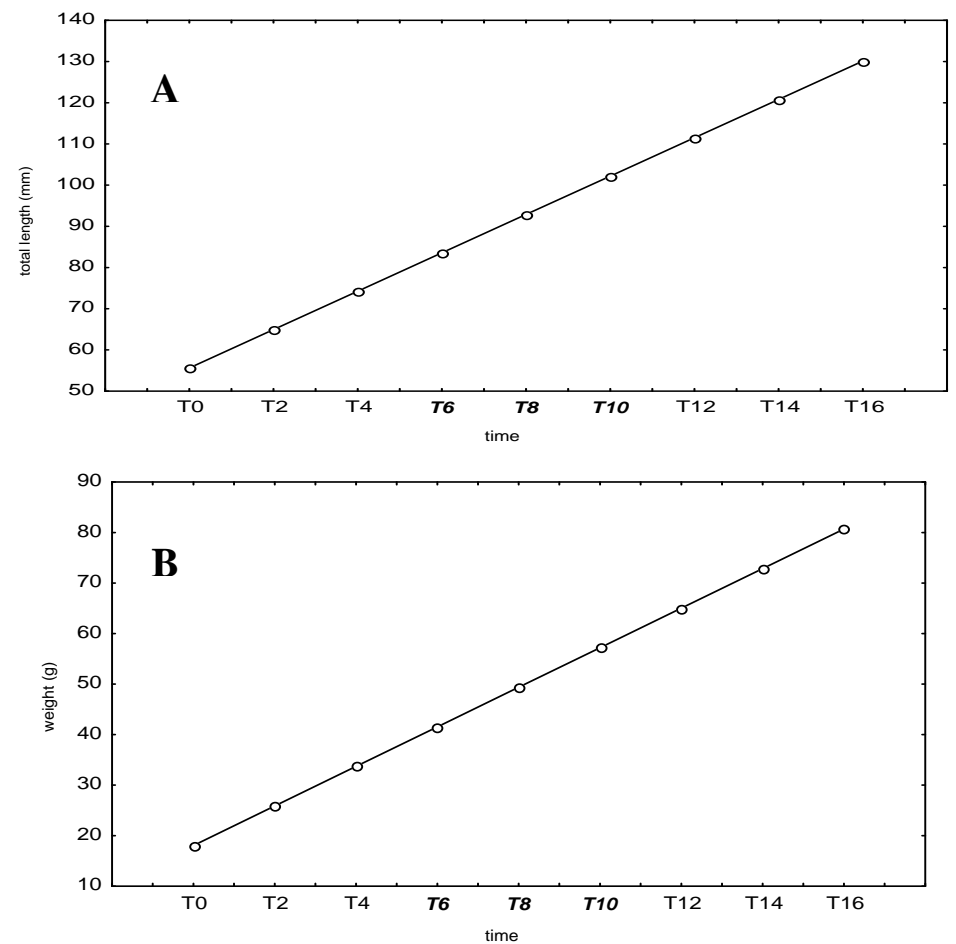

Figure 6A and B - Model adjusted through longitudinal data analysis (Controls and Treatments). A - Total length $(\mathrm{tl})=55.63+4.656 * \mathrm{t} ; \mathrm{t}=$ time $($ biweekly). $\mathbf{B}-$ Weight $(\mathrm{w})=$ $18.05+3.915 * \mathrm{t} ; \mathrm{t}=$ time (biweekly)

\section{DISCUSSION}

Most insecticides used nowadays are part of the organophosphates group, carbamates and synthetic piretroid compounds (Fulton and Key, 2001). These insecticides are commonly used in the elimination of ectoparasites (e.g.: Lernea cyprinaceaea and Gyrodactylus spp.) which cause economical losses in fish cultures (Bakke and Harris, 1998; Gabrielli and Orsi, 2000). The organophosphates (OP) present a toxicity that varies from medium to high, depending on the organism that is affected, contaminating from the invertebrates to aquatic and terrestrial vertebrates. The effects caused by the exposition to the OP have been broadly studied by means of research that monitors the inhibition of the activity of 
acetylcholinesterase enzyme (Pope, 1999; Fulton and Key, 2001; Fanta et al., 2003; Roex et al., 2003; Chandrasekara and Pathiratne, 2005).

Zebrafish, Danio rerio, exposed to Malathion was related to several teratogenic on embryos, connected mainly to the growth of the body length and eye diameters (Cook et al., 2005). Besides the damage caused by Trichlorfon, which included a decrease in growth of the fish weight, appetite loss and motility diminution (Silva de Assis, 1998; Sturm et al., 1999), it was possible to also mention some cases where damages to the fishes were reported, related to the use of different organophosphates and not only Trichlorfon. Cox (1995), using the OP Chlorpyrifos in concentrations lower than a trillionth (ppt), observed the death of different species of the fishes. According to the same author, OP provoked bone abnormalities and reduces growth rates. Even having various studies relating high toxicity of Chlorpyrifos and Trichlorfon for the fishes, the permanence of the active principals of these organophosphates is short in the ambient and in the intoxicated organisms (Resende, 1995). The same cannot be said for the OP Diazinon, which alters erythrocytes and leukocytes index in fishes, causing a decrease in non-specific immunity, and having a malefic effect with prolonged duration (Svoboda et al., 2001). Other OP as Dichlorvos reduced growth rates of Heteropneustes fossilis only when exposed chronically to the pesticide (Pal and Konar, 1985).

This work tested the hypothesis that the treatment against the fishes parasitosis using OP Trichlorfon altered the total length and the weight growth rate of $O$. niloticus. Results showed that that the treated fishes were in average $4.2 \%$ smaller than control animals, although such difference was not significant. In culture environment, treated animals were in average $4.8 \%$ bigger than the control fishe, and were not significantly different from the growth rates of control animals. These results were in contrast to most of the studies, but who similar to the results obtained by Ludwig (1993) who suggested that the use of the pesticides Fenthion, Trichlorfon and Diflubenzuron would not cause any significant difference in length or weight growth in hybrids of Morone saxatilis in culture environment. Same results were related by Ruddle and Zhong (1988), suggesting that no adverse effects existed in the use of Trichlorfon in aquaculture.
In the laboratory experiment, a significant difference occurred in the weight growth of the treated fishes in relation to the control fishes. Probably this occurred due to the fact that these animals were submitted to a greater confinement (relative biomass $=0.58 \mathrm{~g}$ of fish $/ \mathrm{L}$ ), promoting an average difference at the end of the experiment of $54.7 \%$ of weight between the control and the treated fishes. Nevertheless, such growth rates were not considered significantly different when tested by longitudinal analyses.

But in the field experiment, where the animals were submitted to a smaller confinement (relative biomass $=0.02 \mathrm{~g}$ of fish/L), by the end of the experimental period, the treated animals were, in average, $131.9 \%$ heavier than the control fishes, not being considered statistically significant. This suggested that Trichlorfon did not have deleterious action over the fish growth. Longitudinal analysis corroborated such information, indicating that there was no significant difference in the growth pattern in the weight of the control and the treated fishes in the field.

From the difference of the results achieved between the treated and the control animals in the field and laboratory experiments, a hypothesis was raised suggesting that the relative fish biomass in each of these experiment could have influenced in the analyzed growth rates. The treatment with $\mathrm{OP}$ eliminated the parasites from the treated fishes not only in the laboratory, but also in the fied. Initial relative biomass of the animals kept in fish cages (field) was of $0.02 \mathrm{~g}$ of fish/L, and of the fishes kept in the aquaria (laboratory) was of $0.58 \mathrm{~g}$ of fish/L. This hypothesis was in accordance to the information obtained by Scottish fish farmers, which supported the fact that the deleterious effect of Trichlorfon was higher when the fishes concentration were higher in a culture system (Anonymous, 1992). Brown et al. (2004) observed that a xenobiotic-induced (organophosphorous, carbamates, cyanide compounds and others) change thyroid function in the fish promoted a decrease of fitness or survival.

Acute stress situations promote the liberation of glycocorticoids, especially of cortisol, which causes a reduction in the activity of the immune processes (Ellis, 1981). Pickering et al. (1991) and Auperin et al. (1997) showed that cortisol inhibits the circulation of growth hormone $(\mathrm{GH})$ in situations of short period confinements. They also suggest that chronic confinement causes the level of cortisol to remain high, but the circulating 
cortisol returns to normal concentrations, and this adaptive response was due in stress situation. It is suggested that the possible return of normal GH levels promotes the normal and expected increase in total length of the contaminated fish, becoming then similar to control. Yet, elevated levels of cortisol concentration promote a very common symptom stress condition, which is appetite loss (Silva de Assis et al., 1993), affecting animal's general health condition.

It could be suggested that the animals submitted to the treatment in laboratory should probably present a low increase in weight by exhibiting two stress factors: high relative biomass and the exposition to the OP Trichlorfon. Deleterious effects of OP over the fish health might have been even more accentuated by the amount of stocked fish in each aquarium. On the contrary, the animals treated in the field reached a satisfactory growth, possibly due to a smaller initial relative biomass, which did not affect in a negative way the malefic effects that could have been caused by the chemical treatment as, for example, the inhibition of acetylcholinesterase and the decrease of appetite (Silva de Assis et al. 1993). The results of this study could be extrapolated to a real situation of the culture in the limitations of the experiments context. Nowadays, fish culture in Brazil is strongly based in a semi-intensive system, with high densities stocks (high relative biomass), which mostly depends on the use of aerators and great amounts of food. Therefore, if the use of products that contain Trichlorfon as active commencement is needed, this should be done in isolated tanks, and always in low densities (low relative biomass), which will promote a smaller impact over the health and zootechnical parameters of fish. Even with the demonstration that the use of Trichlorfon does not interfere in fish growth, it is evident that the additional care of treatments with chemical products must be taken in consideration. The treatments done in tanks with high densities (high relative biomass) could result in losses in production due to the reduction of growth rate and a consequent increase in production time.

It could be concluded that the treatments against parasitosis that have active commencement as the organophosphates must be performed in tanks that contained low densities and/or relative biomass of the fishes so that would not cause deleterious effects in the fish weight and the total length development. The application of such insecticides must not be used indiscriminately, since other important effects occur, for example the inhibition of the acetylcholinesterase enzyme.

\section{ACKNOWLEDGEMENTS}

We are thankful for the financial and logistic support from the CAPES and to the postgraduation Course in Zoology at the Federal University of Paraná.

\section{RESUMO}

$\mathrm{O}$ atual crescimento da piscicultura nacional tem aumentado a incidência de enfermidades parasitárias que promovem perdas econômicas. Atualmente são utilizados tratamentos com organofosforados para o combate das parasitoses (e.g.: Trichlorfon). Este trabalho tem como objetivo avaliar a influência de Trichlorfon sobre o crescimento de peixes criados em cativeiro. Utilizando como peixe modelo a tilápia (Oreochromis niloticus), foram realizados bioensaios em laboratório e em ambiente de cultivo. Foram feitas biometrias do peso e comprimento total dos animais durante 16 semanas. O tratamento teve início após a sexta semana de biometria, sendo aplicadas cinco doses de 0,25 ppm de Trichlorfon, uma por semana. Os dados foram gerenciados através de análises longitudinais. Em laboratório, os peixes tratados apresentaram uma redução das taxas de crescimento, sendo significativa apenas para a variável peso. Em ambiente de cultivo, o crescimento foi maior nos peixes tratados do que nos controles. Tais resultados indicam que mesmo sendo tóxico, a ação deletéria do Trichlorfon é diretamente proporcional à biomassa relativa (gramas de peixe por litro). Estes resultados sugerem que os tratamentos com produtos que têm como princípio ativo o Trichlorfon devem ser realizados em viveiros/tanques com baixa biomassa relativa/densidade, para evitar o prejuízo da higidez e das características zootécnicas do plantel. 


\section{REFERENCES}

Anonymous (1992), Inter-company agreements mark a turning point. Fish Farmer, 14, 23-24.

Auperin, B., Baroiller, J. F, Ricordel, M. J., Fostier, A. and Prunet, P. (1997), Effect of confinement stress on circulating levels of growth hormone and prolactins in freshwater-adapted tilapia (Oreochromis niloticus). Gen. Comp. Endocrinol., 108 : (1), 5-44.

Bakke, T. A. and Harris, P. D. (1998), Diseases and parasites in wild Atlantic salmon (Salmo salar) populations. Can. J. Fish. Aquat. Sci./J. can. sci. halieut. aquat., 55 : (S1), 247-266.

Brandal, P. O. and Egidius, E. (1979), Treatment of salmon lice (Lepeophtheirus salmonis, Kroter, 1838) with Neguvon - description of method and equipment. Aquaculture, 18, 183-188.

Brown, S. B., Adams, B. A., Cyr, D. G. and Eales, J. G. (2004), Contaminant effects on the teleost fish thyroid. Environ. Toxicol. Chem., 23 : (7), 680-701.

Chandrasekara, H. U. and Pathiratne, A. (2005), Influence of low concentrations of Trichlorfon on haematological parameters and brain acetylcholinesterase activity in common carp, Cyprinus carpio L. Aquac. Res., 36 : (2), 144-149.

Cook, L. W., Paradise, C. J. and Lom, B. (2005), The pesticide malathion reduces survival and growth in developing zebrafish. Environ. Toxicol. Chem., 4 : (7), 1745-50.

Cox, C. (1995), Chlorpyrifos, Part 3: Ecological effects. J. Pest. Reform - Summer, 15 (2) : 13-19.

Ellis, A. E. (1981), Stress and the modulation of defence mechanisms in fish. In-Stress and Fish, ed. A. D. Pickering. Academic Press, London, England, pp. 147-169.

Eto, M. (1974), Organophosphorous Pesticides: Organic and Biological Chemistry. CRC Press., Boca Raton, FL.

Fanta, E., Rios, F., Romão, S., Vianna, A. C., Freiberger, S. (2003), Histopathology of the fish Corydoras paleatus contaminated with sublethal levels of organophosphorus in water and food. Ecotoxicol. Environ. Saf., 54 : (2), 119-30.

FAOSTAT - FAO Statistical Databases (2004), on CDs-ROM. Rome - Italy: FAO.

Fulton, M. H. and Key, P. B. (2001), Acetylcholinesterase inhibition in estuarine fish and invertebrates as an indicator of organophosphorus insecticide exposure and effects. Environ. Toxicol. Chem., 20 : (1), 37-45.

Gabrielli, M. A. and Orsi, M. L. (2000), Dispersão de Lernea cyprinacea (Linnaeus) na região norte do Estado do Paraná, Brasil. Rev. Bras. Zool., 17 : (2), 395-400.
Gesamp (IMO/FAO/UNESCO-IOC/ WMO/ WHO/ IAEA/UN/UNEP Joint Group of Experts on the Scientific Aspects of Marine Environmental Protection) (1997), Towards safe and effective use of chemicals in coastal aquaculture. Rep. Stud. GESAMP (65), 40 p.

Hill, E. F. and Camardese, M. B. (1986), Lethal Dietary Toxicities of Environmental Contaminants to Coturnix, Technical Report Number 2. U.S. Department of Interior, Fish and Wildlife Service, Washington, DC, 5-15.

Hinton, D. E. and Lauren, D. J. (1990), Integrative histopathological approaches to detecting effects of environmental stressors on fishes. Am. Fish. Soc. Symp., 8, 51-66.

Hofer, W. (1981), Chemistry of metrifonate and dichlorvos. Acta Pharmacol. Toxicol., 49 : (5), 7-14.

Howe, G. E., Marking, L. L., Bills, T. D., Rach, J. J. and Mayer, F. L. (1994), Effects of water temperature and $\mathrm{pH}$ on toxicity of terbufos, Trichlorfon, 4nitrophenol and 2,4-dinitrophenol to the amphipod Gammarus pseudolimnaeus and Rainbow Trout (Oncorhynchus mykiss). Environ. Toxicol. Chem., 13, 51-66.

Jones, R. H. (1993), Longitudinal data with serial correlation: a state space approach. Ed. Chapman and Hall. London.

Ludwig, G. M. (1993), Effects of Trichlorfon, fenthion, and diflubenzuron on the zooplankton community and on production of reciprocal-cross hybrid striped bass fry in culture ponds. Aquaculture, 110, 301-319.

Machado, M. R. and Fanta, E. (2003), Effects of the Organophosphorous Methyl Parathion on the Branchial Epithelium of a freshwater fish Metynnis roosevelti. Braz. arch. biol. technol., 46 : (3), 361372.

Mackinnon, B. M. (1997), Sea Lice: a review. World Aquacult., 28 : (3), 5-10.

Messenger, J. L. and Esnault, F. (1992), Traitement par le dichlorvos des copepodoses de la truite arc-en-ciel elevée en mer: modalities de traitement adaptées aux conditions environmentales françaises. InChemotherapy in Aquaculture: From Theory to Reality, ed. C. Michel and D. J. Alderman. Office International des Epizootics, Paris, pp. 195-205.

Murty, A. S. (1986), Toxicity of pesticides to fish Vol II. CRC Press., Boca Raton, FL.

Ostrensky, A. and Boeger, W. (1998), Piscicultura. Fundamentos e Técnicas de Manejo. Livraria e Ed. Agropecuária, Guaíba - RS.

Pal, A. K. and Konar, S. K. (1985), Chronic effects of the organophosphorus insecticide DDVP on feeding, survival, growth and reproduction of fish. Environ. Ecol., 3, 398-402. 
Palacio, J. A., Henao, B., Vélez, J. H., González, J. and Parra, C. M. (2002), Accute toxicity and bioaccumulation of pesticide Diazinon in red tilapia (Oreochromis niloticus x Mossambicus albina). Environ. Toxico., 17 : (4), 334-340.

Pickering, A. D., Pottinger, T. G., Sumpter, J. P., Carrangher, J. F. and Lc-Bail, P.Y. (1991), Effects of acute and chronic stress on the levels of cieculating growth hormone in the rainbow trout, Oncorhynchus mykiss. General and Comparative Endocrinology, $\mathbf{8 3}$ : (1), 86-93.

Pope, C. N. (1999), Organophosphorus pesticides: do they all have the same mechanism of toxicity? $J$. Toxicol. Environ. Health, 2 : (2),161-81.

Resende, E. K. (1995), Influência das atividades antrópicas sobre os peixes da bacia hidrográfica do rio Miranda, período de 1985 a 1987. Corumbá, MS: Embrapa -CPAP, 15, 30 p.

Richmonds, C. and Dutta, H. M. (1989), Histopathological Changes Induced by Malathion in the Gills of Bluegill Lepomis macrochirus. Bull. Environ. Contamin. Toxicol., 43, 123-130.

Roex, E. W., Keijzers, R. and Van Gestel, C. A. (2003), Acetylcholinesterase inhibition and increased food consumption rate in the zebrafish, Danio rerio, after chronic exposure to parathion. Aquat. Toxicol., 64 : (4), 451-60.

Roth, M., Richards, R. H. and Sommerville, C. (1993), Current practices in the chemotherapeutic control of sea lice infestations in aquaculture: a review. J. Fish. Dis., 16, 1-26.

Ruddle, K. and Zhong, G. (1988), Integrated agriculture-aquaculture in South China: the dike-pond system of the Zhujiang Delta. Cambridge University Press, Cambridge.
Sievers, G., Palacios, P., Inostroza, R. and Dölz, H. (1995), Evaluation of the toxicity of 8 insecticides in Salmo salar and the in vitro effects against the isopode parasite, Ceratothoa gaudichaudii. Aquaculture, 134, 9-16.

Silva de Assis, H. C, Medina, H. S. G., Fanta, E., Bacila, M. (1993), Sub-lethal effects of the organophosphate Folidol 600 (Methyl Parathion) on Callichthys callichthys (Pisces, Teleostei). Comp. Biochem. Physiol., 105 C, 197-201.

Sturm, A. Silva de Assis, H. C. and Hansen, P. D. (1999), Cholinesterases of marine teleost fish: enzymological characterization and potential use in the monitoring of neurotoxic contamination. Mar. Environ. Res., 47, 389-398.

Svoboda, M., Lusková, V., Drastichová J., Îlábek, V. (2001), The effect of diazinon on haematological indices of common carp (Cyprinus carpio L.). Acta Vet. Brno, 70 : 457-465.

Tojo, J. L. and Santamarina, M. T. (1998), Oral pharmacological treatments for parasitic diseases of rainbow trout Oncorhynchus mykiss. III Ichthyobodo necator. Dis. Aquat. Org., 33 : (3), 195-199.

Veiga, M. L., Rodrigues, E. L., Pacheco, F. J., RanziniPaiva, M. J. T. (2002), Histopathologic changes in the kidney tissues of Prochilodus lineatus Valenciennes, 1836 (Characiformes, Prochilodontidae) induced by sublethal concentration of Trichlorfon exposure. Braz. arch. biol. technol., 45 : (2), 171-175.

Received: September 29, 2005; Revised: April 18, 2006; Accepted: July 19, 2007. 